\title{
Long-term nitrogen fertilizer replacement value of cattle manures applied to cut grassland
}

\author{
J. J. Schröder • D. Uenk • G. J. Hilhorst
}

Received: 26 January 2007 / Accepted: 20 July 2007 /Published online: 5 September 2007

(C) Springer Science + Business Media B.V. 2007

\begin{abstract}
Manures supply nitrogen (N) to crops beyond the year of application. This $\mathrm{N}$ must be taken into account for agronomic and environmental reasons. From 2002 to 2006 we conducted a field experiment on a sandy soil in The Netherlands $\left(52^{\circ} 03^{\prime \prime} \mathrm{N}, 6^{\circ} 18^{\prime \prime} \mathrm{E}\right)$ to better quantify this residual $\mathrm{N}$ effect. Treatments comprised different time series of mineral fertilizer $\mathrm{N}$ or cattle manures of different compositions, all applied at a rate of $300 \mathrm{~kg}$ total $\mathrm{N}$ $\mathrm{ha}^{-1}$ year $^{-1}$, whilst compensating for differences in available potassium and phosphorus. Dry matter and $\mathrm{N}$ yields of cut grassland responded positively $(P<0.05)$ to both current manure applications and applications in previous years, whereas mineral fertilizer $\mathrm{N}$ affected yields in the year of application only. $\mathrm{N}$ yields could be reasonably well predicted with a simple $\mathrm{N}$ model, adopting an annual relative
\end{abstract}

Responsible Editor: Elizabeth (Liz) A. Stockdale.

J. J. Schröder $(\bowtie) \cdot$ D. Uenk

Plant Science Group, Plant Research International,

Wageningen University and Research Centre,

P.O. Box 16, 6700 AA Wageningen,

The Netherlands

e-mail: jaap.schroder@wur.nl

\section{G. J. Hilhorst}

Animal Science Group,

Experimental Dairy Farm De Marke,

Wageningen University and Research Centre,

Roesinkweg 2,

7255 PC Hengelo, The Netherlands decomposition rate of the organic $\mathrm{N}$ in manure of $0.10-0.33$ year $^{-1}$ during the year of application and 0.10 year $^{-1}$ in the following years. Subsequent model calculations indicated that the $\mathrm{N}$ fertilizer value (NFRV) of injected undigested cattle slurry rises from an observed $51-53 \%$ when slurry is applied for the first time, to approximately $70 \%$ after $7-10$ yearly applications, whereas it took two to four decades of yearly applications to raise the NFRV of surface applied farm yard manure to a similar level from an initial value of $31 \%$. Manures with a relatively high first year NFRV (e.g. anaerobically digested slurry) had a relatively small residual $\mathrm{N}$ effect, whereas manures with a low first year NFRV (e.g. farm yard manure) partly compensated for this by showing larger residual effects. Given the long manuring history of most agricultural systems, rethinking the fertilizer value of manure seems justified. The results also imply that the long term consequences of reduced $\mathrm{N}$ application rates may be underestimated if manuring histories are insufficiently taken into account.

Keywords Cattle manure - Decomposition .

Digested slurry $\cdot$ Fertilizer replacement value .

Grassland $\cdot$ Manure $\cdot$ Nitrogen $\cdot$ Residual effect

\footnotetext{
Abbreviations

NFRV nitrogen fertilizer replacement value, $\%$ $\mathrm{Nm}$ mineral $\mathrm{N}$ in manure
} 
Norg organic $\mathrm{N}$ in manure, $\mathrm{kg} \mathrm{N} \mathrm{ha}^{-1}$

Norg1 $\mathrm{N}$ mineralized from Norg in the year of application, $\mathrm{kg} \mathrm{N}$ ha ${ }^{-1}$

Norg2 $\mathrm{N}$ mineralized from Norg in the years after the year of application, $\mathrm{kg} \mathrm{N}^{-1}$

LON labile soil organic nitrogen, $\mathrm{kg} \mathrm{N} \mathrm{ha}^{-1}$

SON stable soil organic nitrogen, $\mathrm{kg} \mathrm{N} \mathrm{ha}^{-1}$

RDR relative decomposition rate, year ${ }^{-1}$

Nrain atmospherically deposited $\mathrm{N}, \mathrm{kg} \mathrm{N} \mathrm{ha}^{-1}$

Nfert mineral fertilizer $\mathrm{N}, \mathrm{kg} \mathrm{N}^{-1}$

Nloss total losses to air and water, $\mathrm{kg} \mathrm{N} \mathrm{ha}^{-1}$

Ncrop harvested $\mathrm{N}, \mathrm{kg} \mathrm{N}^{-1}$

ANR apparent $\mathrm{N}$ recovery, \%

SMN soil mineral $\mathrm{N}, \mathrm{kg} \mathrm{N}^{-1}$

S1UNi untreated, injected cattle slurry from farm 1

S1ADi anaerobically digested, injected cattle slurry from farm 1

S2UNi untreated, injected cattle slurry from farm 2

S2UNs untreated, surface applied cattle slurry from farm 2

FYMs surface applied cattle farm yard manure

CANs surface applied calcium ammonium nitrate

CONT control treatment receiving $\mathrm{P}$ and $\mathrm{K}$ but no $\mathrm{N}$

\section{Introduction}

Organic manures cause residual nitrogen $(\mathrm{N})$ effects after the year of their application (Whitmore and Schröder 1996; Sörensen and Amato 2002; Sörensen 2004; Sörensen and Thomsen 2005; Daudén et al. 2005; Schröder et al. 2005a). However, the $\mathrm{N}$ fertilizer replacement values (NFRV) of manures communicated to farmers, are commonly based on $\mathrm{N}$ becoming available during the first growing season only (Schröder and Stevens 2004; Gutser et al. 2005; Reijs et al. 2007). If $\mathrm{N}$ provided through earlier applications is not accounted for in one way or another, manured crops may thus receive too much $\mathrm{N}$. A greater awareness of the residual $\mathrm{N}$ effect is required now that cropping systems in the developed world must be redirected towards situations closer to $\mathrm{N}$ limitation for the benefit of the environment (Addiscott 2005). However, farmers point at the reverse side of this coin: when $\mathrm{N}$ recommendations are based on response trials executed on fields that were amply manured in the recent past, yield penalties resulting from withheld $\mathrm{N}$ may be underestimated (Motavalli et al. 1992; Schröder 2005). A better insight in these residual effects is hence also needed from this perspective.

Soil based indicators giving growers reliable estimates of the mineralizable $\mathrm{N}$ potential, are lacking so far (Powlson 1997; Curtin and McCallum 2004). Instead, models predicting available $\mathrm{N}$ as a function of previous organic $\mathrm{N}$ inputs may be helpful. An example of such a model was presented by Schröder et al. (2005a). Their model was calibrated with data from a medium term experiment in which cattle slurry was annually applied to silage maize. The study indicated that the relative decomposition rate (RDR) of the organic $\mathrm{N}$ in slurry amounted to $0.25-$ 0.33 year $^{-1}$. The parameter setting of their model did not need any adjustments to achieve a satisfactory match between observed and simulated $\mathrm{N}$ yields of maize in an independent data set (Schröder et al. 2006). However, lack of regular soil perturbation, may render lower RDR's for manures applied to permanent grassland (Silgram and Shepherd 1997). Moreover, RDR's are affected by the nature of the organic compounds in manure as well (Chae and Tabatabai 1986; Chadwick et al. 2000). Both aspects justify additional research.

The NFRV of manures is not just determined by the RDR of the organic $\mathrm{N}$ fraction but also by the fate of the mineral $\mathrm{N}$ fraction which mainly consists of ammonium $\mathrm{N}$. This form of $\mathrm{N}$ can be easily lost due to volatilization as ammonia $\left(\mathrm{NH}_{3}\right)$. To prevent this loss, slurry injection has become compulsory on grasslands in The Netherlands (Huijsmans 1999). Some farmers question this obligation, arguing that the benefits of injection in terms of a reduced $\mathrm{NH}_{3}$ loss are countered by the detrimental effects of injection on soil and sod quality and thus on $\mathrm{N}$ utilization. Their views are not supported by recent research (Schils and Kok 2003), but there is an ongoing demand for additional evidence (Sonneveld et al. 2007).

This paper reports results of a field experiment on cut grassland directed at the assessment of the NFRV of various types of manures in the year of application and in subsequent years. The paper also includes testing of a simple numerical model allowing exploration of the long term consequences of manure applications on available $\mathrm{N}$ and yield. 


\section{Materials and methods}

Field experiment

In the spring of 2002 an experiment on the $\mathrm{N}$ fertilizer replacement values (NFRV) of manures was started on a free draining slightly loamy, moderately fine sandy soil (FAO classification 'cambic podzol') with an organic matter content of approximately $4 \%$ and a $\mathrm{pH}$ of $5.5(0-20 \mathrm{~cm})$ at the Experimental Dairy Farm 'De Marke' in Hengelo, The Netherlands $\left(52^{\circ} 03^{\prime \prime} \mathrm{N}\right.$, $\left.6^{\circ} 18^{\prime \prime} \mathrm{E}\right)$. Additional soil fertility indicators are presented in Table 1. The experiment was established in permanent (since 1994) grassland with a sward dominated $(>80 \%)$ by Lolium perenne L. Dicots including white clover were chemically controlled for an unbiased assessment of the NFRV (Schröder 2005). The treatments installed from 2002 comprised a control receiving no $\mathrm{N}$ at all (CONT), and treatments receiving $300 \mathrm{~kg}$ total $\mathrm{N} \mathrm{ha}^{-1}$ year $^{-1}$ as surface applied calcium ammonium nitrate (CANs), as sod injected anaerobically digested cattle slurry (S1ADi) or sod injected untreated cattle slurry (S1UNi) from the De Marke farm, as sod injected (S2UNi) or surface applied (S2UNs) untreated cattle slurry from a second farm, and as surface applied solid cattle manure (FYMs) from another farm. The ratio of mineral $\mathrm{N}$ to total $\mathrm{N}$ in these treatments ranged from $100 \%$ in CANs, $59 \%$ in S1ADi, $49-52 \%$ in the other slurries, to $12 \%$ in the FYMs (Table 2). Estimated carbon (C) to organic $\mathrm{N}$ ratio's were reasonably

Table 1 Soil fertility indicators at the onset of the experiment in 2002

\begin{tabular}{lccc}
\hline & \multicolumn{3}{l}{ Layer (cm) } \\
\cline { 2 - 4 } & $0-20$ & $20-40$ & $40-60$ \\
\hline pH-KCl & 5.5 & 5.6 & 5.8 \\
Organic matter, \% by weight & 4.0 & 3.6 & 1.7 \\
Total N, \% by weight & 0.138 & 0.120 & 0.041 \\
C to N ratio & 17 & 18 & 24 \\
Water extractable P ${ }^{\text {a }}$, mg P 1 & \\
Total P, \% by weight & 68 & 67 & 24 \\
HCl extractable K, \% by weight & 0.078 & 0.076 & 0.025 \\
Mg, \% by weight & 0.010 & 0.007 & 0.005 \\
& 0.095 & 0.077 & 0.038 \\
\hline
\end{tabular}

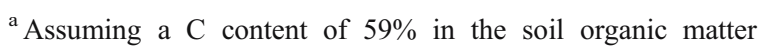
(Lagreid et al. 1999)

${ }^{\mathrm{b}}$ Sissingh 1971 similar (range 14.8-15.8) in all manure types, but the $\mathrm{C}$ to total $\mathrm{N}$ ratio of FYMs was much larger due to the low ammonium $\mathrm{N}$ concentration. Application rates of mineral $\mathrm{P}_{2} \mathrm{O}_{5}$ (triple super phosphate) and $\mathrm{K}_{2} \mathrm{O}$ (muriate of $\mathrm{K}$ ) were adjusted to the different amounts of these elements present in manure to make sure that these elements would not be limiting yields (Table 2). Other nutrients were considered amply available (http://www.bemestingsadvies.nl).

Farm yard manure was applied by hand once a year in the second half of February. The mineral fertilizer $\mathrm{N}$ and slurry applications were split over three dates (around April 1, second half of May after first grass cut, second half of June after second grass cut) in a 120 to 100 to 80 ratio, based on $\mathrm{N}$ contents. Slurries were applied with a precision tanker designed for field trials, equipped with either four splash plates (effective total application width exactly $2.75 \mathrm{~m}$, plate distance $70 \mathrm{~cm}$ ) or injection tines (effective total application width $2.75 \mathrm{~m}$, tine distance $25 \mathrm{~cm}$, tine depth 5-7 cm).

An annually increasing part of each plot was left unfertilized until no $\mathrm{N}$ at all was applied to the grassland in 2006. This provided an increasing number of diverging treatments i.e. plots that had been $\mathrm{N}$ fertilized or manured for four (2002-2005), three (2002-2004), two (2002-2003), one (2002) or no year at all. Thus, the share of plots from which $\mathrm{N}$ was withheld increased and eventually comprised plots that had not received any $\mathrm{N}$ for $1-5$ years. This allowed us to discern the residual $\mathrm{N}$ effects and first year NFRV's.

Treatments were embedded in a randomised block design with four replicates. Manure type (including CANs) was the main factor arranged in plots within blocks, the number of years left unfertilized was the superimposed splitting factor within plots. Size of these subplots measured $12 \mathrm{~m} \times 2.75 \mathrm{~m}$.

Grass was cut four to five times a year in the middle of May, second half of June, first week of August, around September 1 and the second half of October. All treatments were harvested on the same day using a Haldrup forage harvester especially designed for trials. The area cut was the inner $10 \times$ $1.5 \mathrm{~m}$ of each subplot. After assessing the fresh weight per subplot, the harvest was spread over a wooden panel. From this heap a random sample of approximately $500 \mathrm{~g}$ was taken with an auger (content 
Table 2 Application rate $\left(\mathrm{kg} \mathrm{ha}^{-1}\right.$ year $\left.^{-1}\right)$ per treatment and some additional characteristics of the used manures

\begin{tabular}{|c|c|c|c|c|c|c|c|c|}
\hline & & \multicolumn{7}{|c|}{ Treatment } \\
\hline & & CONT & CANs & S1ADi & S1UNi & S2UNi & S2UNs & FYMs \\
\hline \multirow[t]{2}{*}{ Total P } & Average & 62 & 62 & 54 & 57 & 61 & 60 & 68 \\
\hline & s.d. & 4 & 4 & 6 & 7 & 8 & 8 & 22 \\
\hline \multirow[t]{2}{*}{ Fertilizer P } & Average & 62 & 62 & 13 & 17 & 13 & 13 & 0 \\
\hline & s.d. & 4 & 4 & 8 & 9 & 10 & 10 & 0 \\
\hline \multirow[t]{2}{*}{ Total K } & Average & 444 & 444 & 362 & 364 & 367 & 363 & 489 \\
\hline & s.d. & 37 & 37 & 17 & 21 & 73 & 85 & 93 \\
\hline \multirow[t]{2}{*}{ Fertilizer $\mathrm{K}$} & Average & 444 & 444 & 66 & 67 & 81 & 81 & 0 \\
\hline & s.d. & 37 & 37 & 11 & 12 & 67 & 67 & 0 \\
\hline \multirow[t]{2}{*}{ Organic matter } & Average & 0 & 0 & 3,968 & 5,142 & 5,327 & 5,038 & 9,198 \\
\hline & s.d. & 0 & 0 & 432 & 651 & 767 & 469 & 210 \\
\hline \multirow[t]{2}{*}{ Total N } & Average & 0 & 300 & 303 & 306 & 311 & 303 & 307 \\
\hline & s.d. & 0 & 0 & 3 & 3 & 6 & 8 & 49 \\
\hline \multirow[t]{2}{*}{ Mineral N/total N } & Average & 0 & 1.00 & 0.59 & 0.52 & 0.49 & 0.49 & 0.12 \\
\hline & s.d. & 0 & 0 & 0.06 & 0.08 & 0.06 & 0.06 & 0.05 \\
\hline \multirow[t]{2}{*}{ C/total N } & Average & - & - & 5.9 & 7.6 & 7.7 & 7.5 & 13.7 \\
\hline & s.d. & - & - & 0.6 & 1.0 & 1.2 & 0.8 & 2.1 \\
\hline \multirow[t]{2}{*}{ C/organic $\mathrm{N}$} & Average & - & - & 14.8 & 15.8 & 15.0 & 14.8 & 15.7 \\
\hline & s.d. & - & - & 0.9 & 1.4 & 1.5 & 1.0 & 3.1 \\
\hline
\end{tabular}

CONT Control plot receiving mineral fertilizer $\mathrm{P}_{2} \mathrm{O}_{5}$ and $\mathrm{K}_{2} \mathrm{O}$ only; CANS surface applied calcium ammonium nitrate; S1ADi sod injected anaerobically digested slurry from farm 1; SIUNi sod injected untreated slurry from farm $1 ; S 2 U N i$ sod injected untreated slurry from farm 2; S2UNs surface applied untreated slurry from farm 2; FYMs surface applied farm yard manure; s.d. standard deviation (number of observations: 4)

$280 \mathrm{~cm}^{3}$ ) to determine the dry matter (DM) content. This sample was dried for $16 \mathrm{~h}$ at $70^{\circ} \mathrm{C}$ and homogenized after grinding it in a $1 \mathrm{~mm}$ mill. Of this material a $3 \mathrm{~g}$ sample was taken to assess the remaining moisture content by drying for $4 \mathrm{~h}$ at $103^{\circ} \mathrm{C}$. From the remainder a $0.9 \mathrm{~g}$ sample was taken to assess the total $\mathrm{N}$ contents according to Dumas (Macro N, Foss Heraeus).

The apparent $\mathrm{N}$ recovery (ANR) of manure or fertilizer was calculated as the difference of the $\mathrm{N}$ yield of a manured (or fertilized) crop and a control crop, and expressed as a percentage of the total $\mathrm{N}$ input from manure. The cumulative ANR of a manure applied in year $n$ was calculated as the summed differences (over the years $n+m, m$ being 0 and 1, 0, 1 and 2, or $0,1,2$ and 3 ) of the $\mathrm{N}$ yields of crops that had been manured (or fertilized) for the last time in year $n$ and crops that had become controls for the first time in year $n$, expressed as a percentage of the total $\mathrm{N}$ input from manure (or fertilizer) in year $n$. The NFRV of manures was defined as the ANR of manure, expressed as a percentage of the ANR of mineral fertilizer $\mathrm{N}$ in the CANs treatment (Schröder 2005). A mineral fertilizer $\mathrm{N}$ treatment, needed for the calculation of NFRV's, was not included in 2006. The impact of residual $\mathrm{N}$ effects on the NFRV of manures could hence not be determined in 2006. Consequently, NFRV's taking account of the first year residual effect were based on the manure batches of 2002, 2003 and 2004, only. Similarly, NFRV's also taking account of the second year residual effect were based on just the batches of 2002 and 2003, those also taking account of the third year residual effect had to be based on the batch of 2002 only.

Around March 1, prior to fertilizer and manure applications, and immediately after the last cut, soil samples were taken (eight cores of $153 \mathrm{~cm}^{3}$ each per subplot) for determination of soil mineral $\mathrm{N}$ (SMN, including $\mathrm{NO}_{3}$ and $\mathrm{NH}_{4}$ ) in the upper $60 \mathrm{~cm}$ soil layer. After homogenizing this sample, $50 \mathrm{ml}$ soil material was added to $100 \mathrm{ml} 0.01 \mathrm{M} \mathrm{CaCl}_{2}$, shaken during $1 \mathrm{~h}$ at $20^{\circ} \mathrm{C}$ and subsequently filtered. SMN in this filtrate was determined using a continuous flow analyser (TRAACS 800, Bran and Luebbe).

At the onset of the experiment (spring 2002) the soil was sampled $(0-30 \mathrm{~cm})$ to determine total $\mathrm{N}$ 
(Kjeldahl) and organic matter (by loss on ignition) contents by taking 12 cores of $94 \mathrm{~cm}^{3}$ each per block. This observation was repeated after four cropping seasons (spring 2006, eight cores per subplot) in fields that had continuously received one of the manures (or fertilizer-N) or had been control. To estimate the size of the soil $\mathrm{N}$ pool, we multiplied the total soil $\mathrm{N}$ content by the corresponding bulk density. Bulk density was assumed to depend on the C-content of the soil (Whitmore et al. 1992), adopting a C-concentration in the soil of $59 \mathrm{~kg}$ per $100 \mathrm{~kg}$ organic matter (Lagreid et al. 1999).

Weather data were collected at the site. Average temperatures during the growing season (MarchOctober) ranged from $12.2^{\circ} \mathrm{C}$ in 2002 to $14.2^{\circ} \mathrm{C}$ in 2006. The summed precipitation (including irrigation) in this period ranged from $494 \mathrm{~mm}$ in 2002 to $591 \mathrm{~mm}$ in 2006 (Table 3).

\section{Model}

We used the data from the experiment to test a simple $\mathrm{N}$ model. The basic version of this model has been developed by Wolf et al. (1989) and was tested by Wolf and Van Keulen (1989); Osmond et al. (1992), and Schröder and Van Keulen (1997). Schröder et al. (2005a) extended the model with an additional $\mathrm{N}$ pool representing the easily available $\mathrm{N}$ compounds such as those found in slurries. This version of the model was successfully tested with an independent data set (Schröder et al. 2006). In the present version of the model we made a more explicit distinction between the organic- $\mathrm{N}$ and ammonium-N fraction of manure to allow the model to be used for different types of manures. We also decided to allow for different RDR's of organic manure- $\mathrm{N}$ in the year of application

Table 3 Mean daily air temperature, cumulative precipitation and irrigation from May 1 to October 31

\begin{tabular}{|c|c|c|c|c|c|c|}
\hline & \multicolumn{5}{|l|}{ Year } & \multirow{2}{*}{$\begin{array}{l}\text { Long term } \\
\text { average }\end{array}$} \\
\hline & 2002 & 2003 & 2004 & 2005 & 2006 & \\
\hline $\begin{array}{l}\text { Temperature } \\
\left({ }^{\circ} \mathrm{C}\right)\end{array}$ & 12.2 & 13.0 & 13.5 & 13.4 & 14.2 & 12.3 \\
\hline $\begin{array}{l}\text { Precipitation } \\
(\mathrm{mm})\end{array}$ & 469 & 420 & 468 & 467 & 444 & 508 \\
\hline $\begin{array}{l}\text { Irrigation } \\
(\mathrm{mm})\end{array}$ & 25 & 102 & 59 & 57 & 147 & \\
\hline
\end{tabular}

$\left(\mathrm{RDR}_{\text {norg1 }}\right)$ and the years after application $\left(\mathrm{RDR}_{\text {norg2 }}\right)$ to account for initial immobilization (Sörensen 2004) or gradual changes in recalcitrance. In addition to the stable organic soil-N pool (SON) and labile organic soil-N pool (LON) of Wolf et al. (1989), we thus discern a pool of manure $\mathrm{N}$ (Norg) of which a fraction $\mathrm{RDR}_{\text {norg1 }}$ is mineralized in the year of application (Norg1) after which a fraction $\mathrm{RDR}_{\text {norg2 }}$ annually mineralizes from the remaining pool (Norg2) in the years after application (Fig. 1).

In the model, ammonium- $\mathrm{N}$ in manure $(\mathrm{Nm})$, mineral fertilizer-N (Nfert), atmospheric deposition (Nrain), and mineralized $\mathrm{N}$ from the organic $\mathrm{N}$ in manure (Norg) are allocated to losses (Nloss), to the harvestable crop (Ncrop) or to LON, according to transfer coefficients (Table 4). Similarly, N mineralized from LON is allocated to Nloss, Ncrop and SON (Fig. 1). The allocation of fertilizer $\mathrm{N}$ to harvestable crop N and LON was based on Schröder et al. (2007), the complement becoming allocated to Nloss. The transfer efficiency of $\mathrm{Nm}$ to crops and LON is lower, because $10 \%$ (when injected) to $70 \%$ (when surface applied) of the ammonium $\mathrm{N}$ may volatilize as $\mathrm{NH}_{3}$ upon application (Huijsmans 1999). The utilisation of $\mathrm{N}$ liberated from LON and Norg by crops is also lower than that of $\mathrm{N}$ in Nfert, as we assume that $5 \%$ of the mineralization occurs outside the growing season of grass, becoming allocated to Nloss. Thus we intended to acknowledge that the quality of the grass swards during our commonly wet winters may become insufficient to intercept all the $\mathrm{N}$ that may mineralize during brief mild periods. The yearly input via deposition was set at $36 \mathrm{~kg} \mathrm{~N}^{-1}$ (source: National Institute of Public Health and the Environment RIVM, Bilthoven, The Netherlands). Of the N in Nrain $25 \%$ is supposedly deposited outside the growing season of grass and allocated to Nloss (Schröder and Van Keulen 1997). The N that is not inherently lost from $\mathrm{Nm}$ and Nrain, and from mineralized LON and Norg, as described above, is allocated to Ncrop, LON and Nloss in the same way as Nfert.

From Wolf et al. (1989) we adopted that the SON to $\mathrm{LON}$ ratio is 3 in an equilibrium situation and that the coefficient for the transfer of $\mathrm{N}$ from LON to SON is 0.15 . This assumption implies that $\mathrm{RDR}_{\text {son }}$ is 20 times smaller than that $\mathrm{RDR}_{\text {lon }}$ (Wolf et al. 1989). Note that this fixed ratio of RDR's still allows that the 
Fig. 1 Diagram of the model showing the flows of $\mathrm{N}$ from fertilizer (Nfert), rain (Nrain), manure $(\mathrm{Nm}+$ Norg) and labile $(L O N)$ and stable soil organic $\mathrm{N}$ pools $(S O N)$, to losses (Nloss), to the crop (Ncrop), to LON and SON (RDR's referring to the relative decomposition rates of the organic $\mathrm{N}$ pools involved)

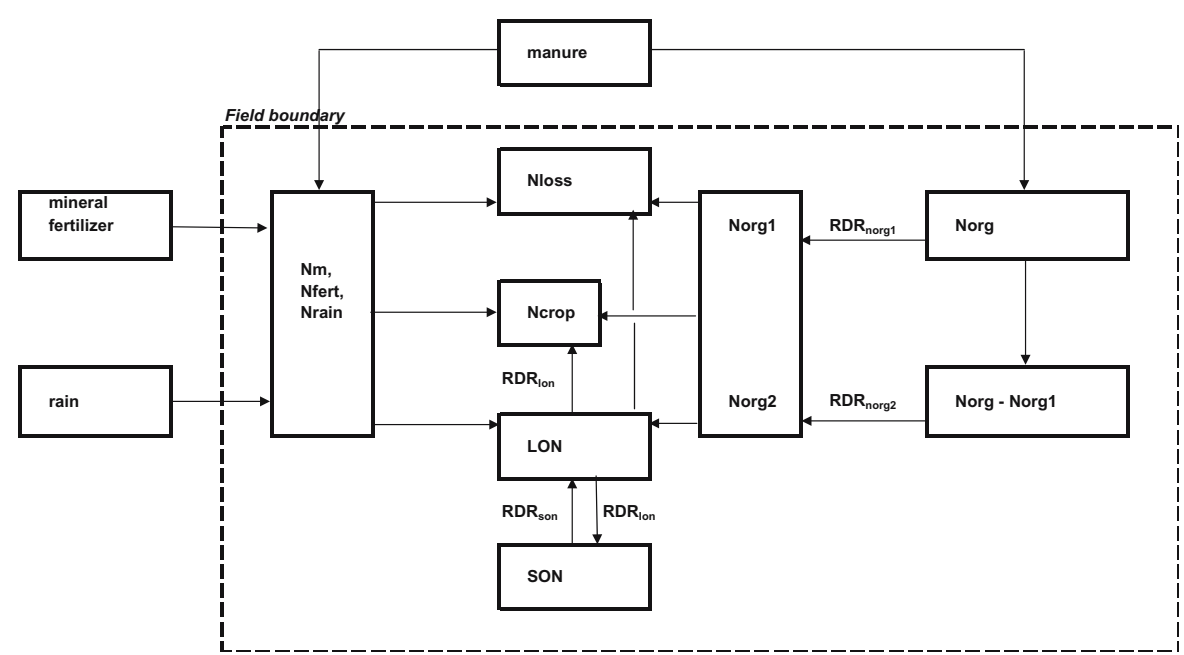

sizes of LON and SON do not have a fixed ratio as long as systems are moving to a new equilibrium.

Trends in the organic $\mathrm{N}$ pool (see results section), made us doubt to use the observed pool size of 2002 as a starting point of our simulations. Instead we used the average of the observations in 2002 and 2006, according to which $\mathrm{LON}+\mathrm{SON}$ amounted to $4,570 \mathrm{~kg}$ $\mathrm{N}$ ha $^{-1}(0-30 \mathrm{~cm})$, after correction for residual $\mathrm{N}$ originating from the estimated $196 \mathrm{~kg}$ total- $\mathrm{N} \mathrm{ha}{ }^{-1}$ applied as undigested cattle slurry in the year before the experiment started.

Testing of the model was restricted to the weighted $\mathrm{RDR}_{\text {lon+son }}$ (as the two are linked, as indicated

Table 4 Transfer coefficients $\left(\mathrm{kg} \mathrm{kg}^{-1}\right)$ of $\mathrm{N}$ in atmospheric deposition (Nrain), in mineral fertilizers (Nfert), ammonium- $\mathrm{N}$ in manure $(\mathrm{Nm})$, in organic $\mathrm{N}$ in manure mineralized in the year of application (Norg1) or the subsequent years (Norg2), in labile soil organic $\mathrm{N}(\mathrm{LON})$ and in stable soil organic $\mathrm{N}(\mathrm{SON})$, to losses to air and soil below the rooted soil profile (Nloss= sum of volatilization, denitrification and leaching), to harvestable crops (Ncrop), to LON and to SON, used in the simulation of direct and residual $\mathrm{N}$ effects of cattle manures and fertilizers applied to cut grassland

\begin{tabular}{|c|c|c|c|c|}
\hline \multirow[t]{2}{*}{ Source } & \multicolumn{4}{|l|}{ Sink } \\
\hline & Nloss & Ncrop & LON & SON \\
\hline Nrain & 0.325 & 0.525 & 0.150 & 0.000 \\
\hline Nfert & 0.100 & 0.700 & 0.200 & 0.000 \\
\hline $\mathrm{Nm}$, when injected & 0.190 & 0.630 & 0.180 & 0.000 \\
\hline $\mathrm{Nm}$, when surface applied & 0.730 & 0.210 & 0.060 & 0.000 \\
\hline Norg1, Norg2 & 0.145 & 0.665 & 0.190 & 0.000 \\
\hline LON & 0.285 & 0.565 & & 0.150 \\
\hline SON & 0.000 & 0.000 & 1.000 & \\
\hline
\end{tabular}

before) and the RDR of Norg $\left(\mathrm{RDR}_{\text {norg1 }}, \mathrm{RDR}_{\text {norg2 }}\right)$. $\mathrm{RDR}_{\text {lon+son }}$ was calculated according to Wolf et al. (1989), based on the $\mathrm{N}$ yields of the long term (20022006) control in 2004, 2005 and 2006 whilst correcting for the contribution from Nrain, the surmised SON/LON ratio, and the estimated size of the soil organic $\mathrm{N}$ pool. Accordingly, a $\mathrm{RDR}_{\text {lon+son }}$ of 0.02 year $^{-1}$ was calculated which is in agreement with Coleman and Jenkinson (1996). In addition to this value we also ran the model with a $\mathrm{RDR}_{\text {lon }+ \text { son }}$ of 0.03 year $^{-1}$, as suggested by the analysis of Schröder et al. (2005a). The model was tested with combinations of $\mathrm{RDR}_{\text {norg1 }}$ values $(0.00,0.10,0.20,0.33$ and 0.50 year $^{-1}$, the latter reflecting the present composition underlying the recommendation for untreated cattle slurry in The Netherlands [Beijer and Westhoek $1996])$ and RDR $_{\text {norg2 }}$ values $(0.10,0.20$ and 0.33 year $^{-1}$ ), thus trying to find a combination that could satisfactorily simulate the observed $\mathrm{N}$ yields. The goodness of fit between simulated and observed data was evaluated with the indices proposed by Addiscott and Whitmore (1987). A good fit between simulated and observed data does not necessarily imply that the model correctly predicts the residual effect of manure whenever a data set includes manure treatments; the good fit could originate from a correct prediction of the first year NFRV rather than of residual $\mathrm{N}$ effects. Therefore, we first analysed plots not receiving any $\mathrm{N}$ in a given year (just reacting to residual N). We excluded the control plot of 2002 from this analysis because application rates and manure composition in the years preceding our experiment were estimated instead of recorded. 
Subsequently, we repeated the analysis after extending the data set with treatments that were manured in a given year. Subsequently the model was used to explore the consequences of repeated manure applications on their long term NFRV's and on the impact of suboptimal fertilizer $\mathrm{N}$ applications on yield depressions.

According to the literature (e.g. Hart et al. 1993) organic inputs to the soil may gradually become more and more recalcitrant, eventually resulting in RDR's close to the $\mathrm{RDR}_{\text {lon+son. If our observations over, at }}$ most, four residual years would not confirm these diminishing RDR's, it could thus be incorrect to apply the $\mathrm{RDR}_{\text {norg2 }}$, as calculated via the above procedure, to years beyond the 4 years for which the model was actually calibrated. We have hence decided to explore the long-term NFRV's and yield depressions according to a scenario in which we assumed the RDR to remain constant over time ('constant RDR') and a scenario in which we assumed the RDR to diminish ('diminishing RDR'). In the latter scenario $\mathrm{RDR}_{\text {norg } 1}$ > $\mathrm{RDR}_{\text {norg2 }}$ with $\mathrm{RDR}_{\text {norg2 }}$ gradually dropping in steps of 0.01 year $^{-1}$ from its estimated value during the first four residual years to our estimated value of $\mathrm{RDR}_{\text {lon }+ \text { son. }}$.

\section{Results}

Field experiment

Dry matter yields of cut grassland were strongly related to their $\mathrm{N}$ yields (Fig. 2) which, in turn, responded positively $(P<0.05)$ to fertilizer $\mathrm{N}$ and manure in all years. The results indicated that manure also had a positive effect on $\mathrm{N}$ yields after the year of application, whereas such an effect was not observed where mineral fertilizer $\mathrm{N}$ (CANs) had been applied in the previous year (Table 5). This residual $\mathrm{N}$ effect of manure was strongest in the first year after application and faded away afterwards.

In the spring of 2003 the content of soil mineral N (SMN, 0-60 cm) of FYMs exceeded SMN of CANs by $10 \mathrm{~kg} \mathrm{~N}$ ha $^{-1}(P<0.05)$. Differences at all other moments amounted to less than $2 \mathrm{~kg} \mathrm{~N} \mathrm{ha}{ }^{-1}$, on average (range -7 to +6 ), and were not significant (Fig. 3). SMN of the other manure types (data not shown) fell in between the values of CANs and FYMs. Consequently, residual $\mathrm{N}$ effects of manures must have resulted from mineralization within the growing season rather than from carry-over of residual SMN from previous seasons.

As the amounts of applied total $\mathrm{N}$ slightly deviated from the intended annual rate of $300 \mathrm{~kg} \mathrm{~N} \mathrm{ha}^{-1}$ (apart from CANs treatments, Table 2) and the $\mathrm{N}$ yields of controls differed per main plot (Table 5), comparisons of effects of the separate manure types must be made relative to their exact rates, i.e. by comparing the ANR's. The experimental design allowed us to determine the cumulative ANR over two consecutive years $(n, n+1)$ for four manure batches $(2002,2003$, 2004 and 2005), the cumulative ANR over 3 years ( $n$, $n+1, n+2)$ for three batches (2002, 2003 and 2004), and the cumulative ANR over 2 years $(n, n+1)$ for two batches (2002, 2003). Residual N effects of manures in the fifth year after application were small (Table 5) and ANR's including this year are not
Fig. 2 Observed relationship between the $\mathrm{N}$ yield and the dry matter $(D M)$ yield of cut grassland, the solid line reflecting the fitted relationship, the straight dotted lines reflecting set $\mathrm{N}$ concentrations in grass dry matter

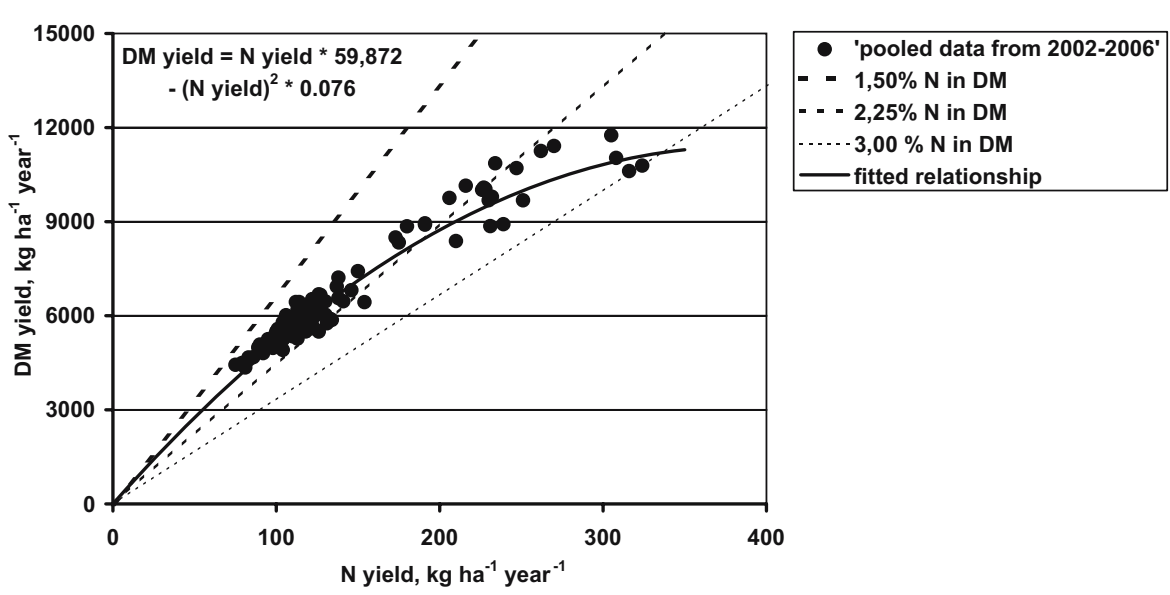


Table 5 Annual nitrogen yield of cut grassland $\left(\mathrm{kg} \mathrm{N}^{-1}\right)$, as affected by manure type and manuring history

\begin{tabular}{|c|c|c|c|c|c|c|}
\hline \multirow[t]{2}{*}{ Manure type } & \multirow[t]{2}{*}{ Manured in years } & \multicolumn{5}{|l|}{ Year } \\
\hline & & 2002 & 2003 & 2004 & 2005 & 2006 \\
\hline \multirow[t]{5}{*}{ CANs } & None & $134 \mathrm{a}^{\mathrm{a}}$ & $111 \mathrm{a}$ & $90 \mathrm{a}$ & $92 \mathrm{a}$ & $113 \mathrm{a}$ \\
\hline & 2002 & $316 \mathrm{~b}$ & $115 \mathrm{a}$ & $99 \mathrm{a}$ & $104 \mathrm{a}$ & $112 \mathrm{a}$ \\
\hline & $2002-2003$ & & $308 \mathrm{~b}$ & $79 \mathrm{a}$ & $98 \mathrm{a}$ & $113 \mathrm{a}$ \\
\hline & 2002-2004 & & & $305 \mathrm{~b}$ & $81 \mathrm{a}$ & $106 \mathrm{a}$ \\
\hline & $2002-2005$ & & & & $324 \mathrm{~b}$ & $121 \mathrm{a}$ \\
\hline \multirow[t]{5}{*}{ S1ADi } & None & $123 \mathrm{a}$ & $111 \mathrm{a}$ & 89 a & $106 \mathrm{a}$ & $106 \mathrm{ab}$ \\
\hline & 2002 & $239 \mathrm{~b}$ & $113 \mathrm{a}$ & $97 \mathrm{a}$ & $113 \mathrm{a}$ & $104 \mathrm{ab}$ \\
\hline & 2002-2003 & & $230 \mathrm{~b}$ & $101 \mathrm{a}$ & $113 \mathrm{a}$ & $103 \mathrm{a}$ \\
\hline & 2002-2004 & & & $227 \mathrm{~b}$ & $127 \mathrm{a}$ & $114 a b$ \\
\hline & $2002-2005$ & & & & $262 \mathrm{~b}$ & $121 \mathrm{~b}$ \\
\hline \multirow[t]{5}{*}{ S1UNi } & None & $131 \mathrm{a}$ & $107 \mathrm{a}$ & $86 \mathrm{a}$ & $95 \mathrm{a}$ & $104 \mathrm{a}$ \\
\hline & 2002 & $231 \mathrm{~b}$ & $130 \mathrm{a}$ & $94 \mathrm{ab}$ & $104 \mathrm{a}$ & $114 \mathrm{ab}$ \\
\hline & $2002-2003$ & & $226 \mathrm{~b}$ & $108 \mathrm{~b}$ & $106 \mathrm{a}$ & $120 \mathrm{ab}$ \\
\hline & 2002-2004 & & & $216 \mathrm{c}$ & $138 \mathrm{~b}$ & $126 \mathrm{~b}$ \\
\hline & $2002-2005$ & & & & $270 \mathrm{c}$ & $124 \mathrm{~b}$ \\
\hline \multirow[t]{5}{*}{ S2UNi } & None & $130 \mathrm{a}$ & $110 \mathrm{a}$ & $75 \mathrm{a}$ & $92 \mathrm{a}$ & $113 \mathrm{a}$ \\
\hline & 2002 & $251 \mathrm{~b}$ & $122 \mathrm{a}$ & $83 a b$ & $95 \mathrm{a}$ & $106 \mathrm{a}$ \\
\hline & $2002-2003$ & & $228 \mathrm{~b}$ & $100 \mathrm{~b}$ & $109 \mathrm{ab}$ & $114 \mathrm{a}$ \\
\hline & 2002-2004 & & & $191 \mathrm{c}$ & $115 \mathrm{~b}$ & $110 \mathrm{a}$ \\
\hline & $2002-2005$ & & & & $247 \mathrm{c}$ & $133 \mathrm{~b}$ \\
\hline \multirow[t]{5}{*}{ S2UNs } & None & $141 \mathrm{a}$ & $120 \mathrm{a}$ & $90 \mathrm{a}$ & $111 \mathrm{a}$ & $125 \mathrm{ab}$ \\
\hline & 2002 & $232 \mathrm{~b}$ & $117 \mathrm{a}$ & $101 \mathrm{a}$ & $114 \mathrm{ab}$ & $122 \mathrm{a}$ \\
\hline & $2002-2003$ & & $191 \mathrm{~b}$ & $104 \mathrm{a}$ & $127 \mathrm{ab}$ & $122 \mathrm{a}$ \\
\hline & 2002-2004 & & & $173 \mathrm{~b}$ & $137 \mathrm{~b}$ & $118 \mathrm{a}$ \\
\hline & $2002-2005$ & & & & $206 \mathrm{c}$ & $138 \mathrm{~b}$ \\
\hline \multirow[t]{5}{*}{ FYMs } & None & $154 \mathrm{a}$ & $126 \mathrm{a}$ & $80 \mathrm{a}$ & $98 \mathrm{a}$ & $117 \mathrm{a}$ \\
\hline & 2002 & $210 \mathrm{~b}$ & $114 \mathrm{a}$ & $92 \mathrm{ab}$ & $109 \mathrm{a}$ & $122 \mathrm{a}$ \\
\hline & $2002-2003$ & & $175 \mathrm{~b}$ & $113 \mathrm{~b}$ & $123 \mathrm{a}$ & $125 \mathrm{a}$ \\
\hline & 2002-2004 & & & $180 \mathrm{c}$ & $150 \mathrm{~b}$ & $131 \mathrm{ab}$ \\
\hline & $2002-2005$ & & & & $234 \mathrm{c}$ & $146 \mathrm{~b}$ \\
\hline
\end{tabular}

Bold numbers refer to manured treatments in the specified year.

CANS Surface applied calcium ammonium nitrate; S1ADi sod injected anaerobically digested slurry from farm $1 ; S 1 U N i$ sod injected untreated slurry from farm 1; S2UNi sod injected untreated slurry from farm 2; S2UNs surface applied untreated slurry from farm 2; FYMs surface applied farm yard manure

${ }^{\text {a }}$ Different letters within manure types and columns denote significant $(P<0.05)$ difference.

shown separately. Our analysis of $\mathrm{N}$ recoveries indicated that the ANR decreased in the order CANs $>$ (S1ADi, S1UNi, S2UNi) $>$ (S2UNs, FYMs), generally showing a positive relationship between the ANR and the mineral $\mathrm{N}$ to total $\mathrm{N}$ ratio of the manure. Observed ANR of the CANs treatment (Table 6) confirmed the efficient transfer of Nfert to Ncrop assumed by us in Table 4. ANR's of manure-N increased with time contrary to the ANR of mineral fertilizer-N. This increment was not any larger for FYM and after 4 years ANR had thus not yet reached the level attained by the injected slurries. ANR of injected slurry (S2UNi) exceeded ANR of surface applied slurry (S2UNs).

The fate of the $\mathrm{N}$ not recovered in harvested crops (i.e. approximately $(100-\mathrm{ANR}) / 100 \times 300 \mathrm{~kg} \mathrm{~N} \mathrm{ha}^{-1}$ year ${ }^{-1}$ ) could not be fully elucidated. A fraction of the applied ammonium must inevitably have volatilized from the manures, especially when surface applied (S2UNs, FYMs). Accumulation as SMN was insignificant (Fig. 3), leaving leaching, denitrification and storage in soil organic $\mathrm{N}$ as potential output terms. 
Fig. 3 Observed soil mineral N (SMN, 0-60 cm layer), as affected by farm yard manure relative to calcium ammonium nitrate applied at annual rates of $300 \mathrm{~kg}$ total $\mathrm{N} \mathrm{ha}^{-1}$ and the unfertilized control (error bars referring to standard errors of means, $n=4$ )

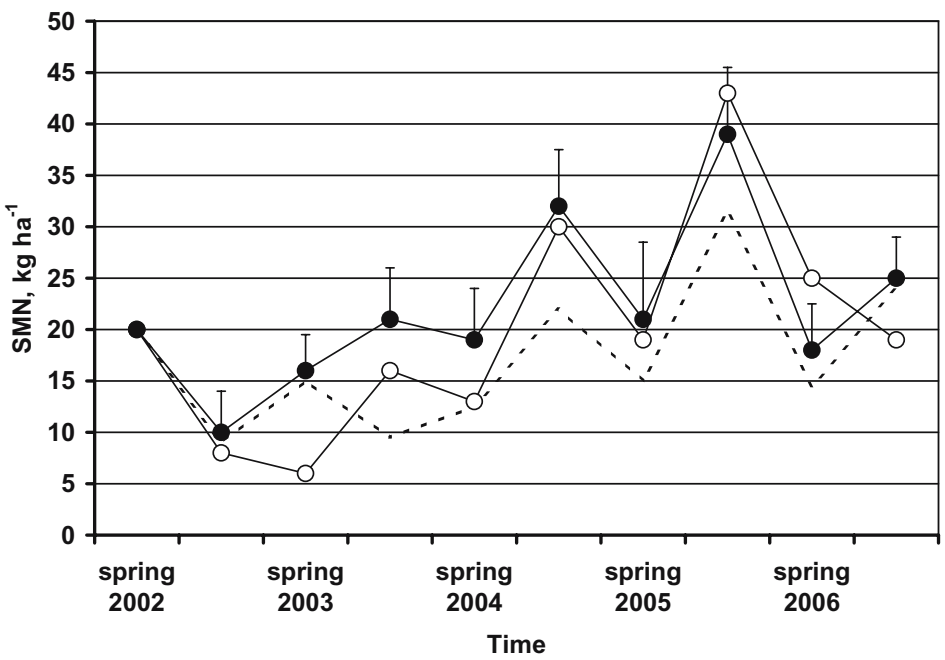

Comparison of total soil $\mathrm{N}$ pools $(0-30 \mathrm{~cm}$ layer) in the springs of 2002 and 2006 pointed at depletion rather than accumulation of soil organic $\mathrm{N}$ (Fig. 4). It must be noted that the calculated annual decline rates of $150 \mathrm{~kg} \mathrm{~N}^{-1}$ (CONT, CANs) to $300 \mathrm{~kg} \mathrm{~N} \mathrm{ha}^{-1}$ (FYMs) of this soil pool are unrealistically high. The errors associated with their measurement strongly question the reliability of their absolute values. The relative decline in FYMs was smaller than in CONT and CANs. This suggests that some of the $\mathrm{N}$ input of FYMs had been stored in organic matter as yet. The size of the $\mathrm{N}$ pools of other treatments (data not shown) fell in between the values of CANs and FYMs.

The average NFRV of digested slurry amounted to $58 \%$ in the first year. Including the residual $\mathrm{N}$ effect in the second year (first residual year), increased the NFRV by $3 \%(=62-59 \%)$ to $61 \%$. Including the residual $\mathrm{N}$ effect in the third and fourth year, increased the NFRV by another $2 \%(=64-62 \%)$ and $4 \% \quad(=71-67 \%)$, respectively. Corresponding NFRV's of undigested slurry in the first, the first two, the first three and the first 4 years, averaged 51$53 \%, 58-61 \%, 61-63 \%$ and $64-67 \%$, respectively

Table 6 Cumulative apparent nitrogen recovery (ANR, \%) from manure in cut grassland after 1 or 2 years (average of the four batches applied in 2002, 2003, 2004 and 2005), after 1, 2 or 3 years (average of the three batches applied in 2002, 2003 and 2004), and after 1,2, 3 or 4 years (average of the two batches applied in 2002 and 2003) as affected by the manure type

\begin{tabular}{|c|c|c|c|c|c|c|}
\hline \multirow[t]{2}{*}{ First year ANR and cumulative ANR } & \multicolumn{6}{|c|}{ Manure type } \\
\hline & CANs & S1ADi & S1UNi & S2UNi & S2UNs & FYMs \\
\hline First year & $70 \mathrm{a}^{\mathrm{a}}$ & $41 \mathrm{~b}$ & $36 \mathrm{c}$ & $37 \mathrm{bc}$ & $24 \mathrm{~d}$ & $22 \mathrm{~d}$ \\
\hline First + second year & $69 \mathrm{a}$ & $43 \mathrm{~b}$ & $41 \mathrm{~b}$ & $42 \mathrm{~b}$ & $27 \mathrm{c}$ & $26 \mathrm{c}$ \\
\hline First year & $67 \mathrm{a}$ & $39 \mathrm{~b}$ & $33 \mathrm{~b}$ & $35 \mathrm{~b}$ & $25 \mathrm{c}$ & $22 \mathrm{c}$ \\
\hline First + second year & $63 \mathrm{a}$ & $43 \mathrm{~b}$ & $41 \mathrm{~b}$ & $38 \mathrm{~b}$ & $26 \mathrm{c}$ & $25 \mathrm{c}$ \\
\hline First + second + third year & $63 \mathrm{a}$ & $45 \mathrm{~b}$ & $42 \mathrm{~b}$ & $40 \mathrm{~b}$ & $29 \mathrm{c}$ & $30 \mathrm{c}$ \\
\hline First year & $0.63 \mathrm{a}$ & $0.38 \mathrm{~b}$ & $0.32 \mathrm{~b}$ & $0.37 \mathrm{~b}$ & $0.27 \mathrm{c}$ & $0.22 \mathrm{c}$ \\
\hline First + second year & $0.60 \mathrm{a}$ & $0.39 \mathrm{~b}$ & $0.38 \mathrm{~b}$ & $0.42 \mathrm{~b}$ & $0.27 \mathrm{c}$ & $0.23 \mathrm{c}$ \\
\hline First + second + third year & $0.60 \mathrm{a}$ & $0.40 \mathrm{~b}$ & $0.40 \mathrm{~b}$ & $0.45 \mathrm{~b}$ & $0.31 \mathrm{bc}$ & $0.27 \mathrm{c}$ \\
\hline First + second + third + fourth year & $0.62 \mathrm{a}$ & $0.41 \mathrm{~b}$ & $0.43 \mathrm{ab}$ & $0.47 \mathrm{a}$ & $0.32 \mathrm{~b}$ & $0.30 \mathrm{~b}$ \\
\hline
\end{tabular}

CANS Surface applied calcium ammonium nitrate; S1ADi sod injected anaerobically digested slurry from farm 1; S1UNi sod injected untreated slurry from farm 1; S2UNi sod injected untreated slurry from farm 2; S2UNS surface applied untreated slurry from farm 2; FYMs surface applied farm yard manure

${ }^{\text {a }}$ Different letters within rows denote significant $(P<0.05)$ differences. 
Fig. 4 Size of the N pool in the upper $30 \mathrm{~cm}$ soil layer at the onset of the experiment and after 5 years, as affected by four annual applications of fertilizer $\mathrm{N}$ (calcium ammonium nitrate, $C A N S$ ) or farm yard manure $(F Y M s)$, relative to the control (error bars referring to standard errors of means, $n=4$ )

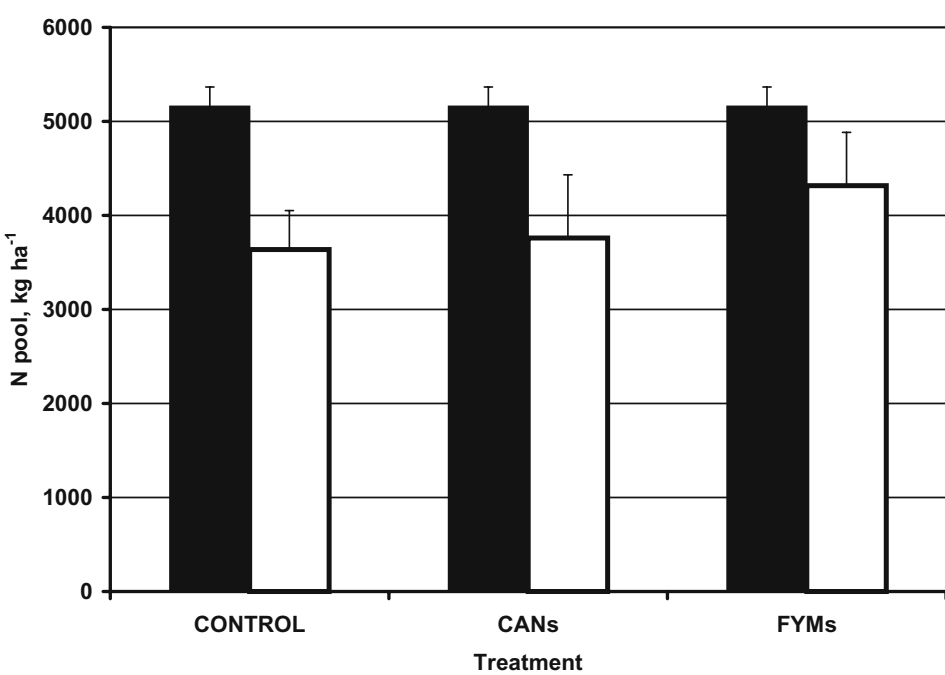

apring 2002
(Table 7). The NFRV of surface applied undigested S2UNs was much lower. There were no signs that the low first year NFRV of S2UNs was compensated by increased residual contributions. FYM's showed the lowest NFRV, their residual contributions to the NFRV in terms of percentages not being any larger than those of slurries. In general the data could not confirm that the gain in NFRV diminished with each next year that was included in the calculation.
Model

Simulations overestimated the observed $\mathrm{N}$ yields of cut grassland responding to residual $\mathrm{N}$ by, on average, $23 \mathrm{~kg} \mathrm{~N}^{-1}$ year $^{-1}$ when a $\mathrm{RDR}_{\text {lon }+ \text { son }}$ of 0.03 year $^{-1}$ was adopted (data not shown), whereas this difference was $6 \mathrm{~kg} \mathrm{~N} \mathrm{ha}^{-1}$ year $^{-1}$ when the RDR was set at 0.02 year $^{-1}$. This made us decide to continue our simulations with the latter value.

Table $7 \mathrm{~N}$ fertilizer replacement value (NFRV, $\mathrm{kg} \mathrm{N}$ per $100 \mathrm{~kg} \mathrm{~N}$ applied) of manures applied to cut grassland after 1 year (average of the four batches applied in 2002, 2003, 2004 and 2005), after 1 or 2 years (average of the three batches applied in 2002, 2003 and 2004), after 1, 2 or 3 years (average of the two batches applied in 2002 and 2003), and after 1, 2, 3 or 4 years (average of the batch applied in 2002)

\begin{tabular}{|c|c|c|c|c|c|}
\hline \multirow[t]{2}{*}{ First year NFRV and cumulative NFRV } & \multicolumn{5}{|c|}{ Manure type } \\
\hline & S1ADi & S1UNi & S2UNi & S2UNs & FYMs \\
\hline First year & $58 \mathrm{a}^{\mathrm{a}}$ & $51 \mathrm{~b}$ & $53 \mathrm{ab}$ & $36 \mathrm{c}$ & $31 \mathrm{c}$ \\
\hline First year & $59 \mathrm{a}$ & $50 \mathrm{~b}$ & $53 \mathrm{ab}$ & $38 \mathrm{c}$ & $33 \mathrm{c}$ \\
\hline First + second year & $62 \mathrm{a}$ & $60 \mathrm{a}$ & $58 \mathrm{a}$ & $39 \mathrm{~b}$ & $37 \mathrm{~b}$ \\
\hline First year & $61 \mathrm{a}$ & $52 \mathrm{a}$ & $59 \mathrm{a}$ & $43 \mathrm{~b}$ & $34 \mathrm{~b}$ \\
\hline First + second year & $62 \mathrm{a}$ & $61 \mathrm{a}$ & 66 a & $43 \mathrm{~b}$ & $35 \mathrm{~b}$ \\
\hline First + second + third year & $64 \mathrm{ab}$ & $63 \mathrm{~b}$ & $71 \mathrm{a}$ & $48 \mathrm{c}$ & $41 \mathrm{c}$ \\
\hline First year & $63 \mathrm{a}$ & $54 \mathrm{ab}$ & $66 \mathrm{a}$ & $49 \mathrm{bc}$ & $34 \mathrm{c}$ \\
\hline First + second year & $64 \mathrm{a}$ & $66 \mathrm{a}$ & $73 \mathrm{a}$ & $48 \mathrm{~b}$ & $26 \mathrm{c}$ \\
\hline First + second + third year & $67 \mathrm{a}$ & $70 \mathrm{a}$ & $76 \mathrm{a}$ & $53 \mathrm{~b}$ & $32 \mathrm{c}$ \\
\hline First + second + third + fourth year & $71 \mathrm{a}$ & $74 \mathrm{a}$ & $77 \mathrm{a}$ & $54 \mathrm{~b}$ & $37 \mathrm{c}$ \\
\hline
\end{tabular}

$S 1 A D i$ Sod injected anaerobically digested slurry from farm $1 ; S I U N i$ sod injected untreated slurry from farm $1 ; S 2 U N i$ sod injected untreated slurry from farm 2; $S 2 U N s$ surface applied untreated slurry from farm 2; FYMs surface applied farm yard manure

${ }^{a}$ Different letters within rows denote significant $(P<0.05)$ differences. 
Table 8 Statistical indices for the goodness of fit between observed and simulated $\mathrm{N}$ yields of cut grassland resulting from just the residual $\mathrm{N}$ effects (RES) of surface applied farmyard manure (FYMs) and injected anaerobically digested slurry (S1ADi), as related to the relative decomposition rates (RDR) of organic $\mathrm{N}$ during the year of application $\left(\mathrm{RDR}_{\text {norg1 }}\right.$, year ${ }^{-1}$ ) and during subsequent years $\left(\mathrm{RDR}_{\text {norg2}}\right.$, year $\left.^{-1}\right)$

\begin{tabular}{|c|c|c|c|c|c|c|c|c|c|}
\hline Manure type & Treatments & Number of observations & $\mathrm{RDR}_{\text {norg1 }}$ & $\mathrm{RDR}_{\text {norg2 }}$ & $\mathrm{M}^{\mathrm{a}}$ & $\mathrm{SE}_{M}^{\mathrm{b}}$ & $R^{\mathrm{c}}$ & $\pm 10^{\mathrm{d}}$ & $\pm 20^{\mathrm{d}}$ \\
\hline \multirow[t]{15}{*}{ FYMs } & \multirow[t]{15}{*}{ RES } & \multirow[t]{15}{*}{14} & \multirow[t]{3}{*}{0.00} & 0.10 & 5 & 3.9 & 71 & 50 & 71 \\
\hline & & & & 0.20 & 21 & 6.5 & 70 & 14 & 43 \\
\hline & & & & 0.33 & 34 & 10.0 & 67 & 14 & 43 \\
\hline & & & \multirow[t]{3}{*}{0.10} & 0.10 & 2 & 3.7 & 71 & 50 & 79 \\
\hline & & & & 0.20 & 17 & 5.8 & 70 & 29 & 50 \\
\hline & & & & 0.33 & 29 & 8.8 & 67 & 14 & 43 \\
\hline & & & \multirow[t]{3}{*}{0.20} & 0.10 & 0 & 3.7 & 71 & 50 & 79 \\
\hline & & & & 0.20 & 13 & 5.1 & 70 & 29 & 64 \\
\hline & & & & 0.33 & 23 & 7.7 & 67 & 29 & 43 \\
\hline & & & \multirow[t]{3}{*}{0.33} & 0.10 & -3 & 3.7 & 70 & 57 & 79 \\
\hline & & & & 0.20 & 8 & 4.4 & 70 & 43 & 71 \\
\hline & & & & 0.33 & 17 & 6.4 & 67 & 29 & 50 \\
\hline & & & \multirow[t]{3}{*}{0.50} & 0.10 & -7 & 3.8 & 69 & 36 & 79 \\
\hline & & & & 0.20 & 1 & 3.9 & 69 & 50 & 79 \\
\hline & & & & 0.33 & 8 & 4.9 & 66 & 43 & 64 \\
\hline \multirow[t]{15}{*}{ S1ADi } & \multirow[t]{15}{*}{ RES } & \multirow[t]{15}{*}{14} & \multirow[t]{3}{*}{0.00} & 0.10 & 6 & 2.6 & 55 & 50 & 93 \\
\hline & & & & 0.20 & 16 & 3.8 & 57 & 36 & 57 \\
\hline & & & & 0.33 & 22 & 5.3 & 57 & 36 & 43 \\
\hline & & & \multirow[t]{3}{*}{0.10} & 0.10 & 5 & 2.5 & 54 & 64 & 93 \\
\hline & & & & 0.20 & 13 & 3.5 & 57 & 36 & 64 \\
\hline & & & & 0.33 & 19 & 4.8 & 56 & 36 & 43 \\
\hline & & & \multirow[t]{3}{*}{0.20} & 0.10 & 3 & 2.4 & 53 & 71 & 100 \\
\hline & & & & 0.20 & 11 & 3.2 & 56 & 43 & 79 \\
\hline & & & & 0.33 & 16 & 4.3 & 56 & 36 & 64 \\
\hline & & & \multirow[t]{3}{*}{0.33} & 0.10 & 1 & 2.3 & 51 & 79 & 100 \\
\hline & & & & 0.20 & 8 & 2.8 & 55 & 57 & 93 \\
\hline & & & & 0.33 & 12 & 3.7 & 55 & 36 & 79 \\
\hline & & & \multirow[t]{3}{*}{0.50} & 0.10 & -1 & 2.3 & 48 & 79 & 100 \\
\hline & & & & 0.20 & 4 & 2.5 & 53 & 71 & 93 \\
\hline & & & & 0.33 & 7 & 3.0 & 54 & 57 & 93 \\
\hline
\end{tabular}

${ }^{\mathrm{a}}$ Mean difference between observed and simulated values, positive values denoting underestimated yields in simulation ( $\mathrm{kg} \mathrm{N}^{-1}$ )

${ }^{\mathrm{b}}$ Standard error of the mean difference $\left(\mathrm{kg} \mathrm{N} \mathrm{ha}^{-1}\right)$

${ }^{\mathrm{c}}$ Coefficient of correlation (\%)

${ }^{\mathrm{d}}$ Percentage of simulations within \pm 10 or $\pm 20 \mathrm{~kg} \mathrm{~N} \mathrm{ha}^{-1}$ year $^{-1}$ of the corresponding observations

This analysis indicated that any value of $\mathrm{RDR}_{\text {norg } 1}$ between 0.10 and 0.33 combined with a $\mathrm{RDR}_{\text {norg2 }}$ of 0.10 year $^{-1}$, yielded the best compromise of relatively low mean differences between observed and simulated $\mathrm{N}$ yields and relatively high correlations between both. Values of 0.00 or 0.50 year $^{-1}$ for $\mathrm{RDR}_{\text {norg1 }}$ and values of 0.20 or 0.33 year $^{-1}$ for $\mathrm{RDR}_{\text {norg2 }}$ made the model perform less. No clear distinction could be found between the two contrasting manure types FYMs and S1ADi (Table 8, other manures not shown separately) which made us decide to pool the data (Table 9).

$\mathrm{N}$ yields of fertilized grassland were systematically underestimated by the model in the first year (2002), as illustrated with the run in which $\mathrm{RDR}_{\text {norg1 }}$ was set at 0.33 and $\mathrm{RDR}_{\text {norg2 }}$ at 0.10 year $^{-1}$ (Fig. 5). This deviation could not be attributed to atypical weather conditions in 2002 (Table 2). When all treatments were pooled, absolute differences between observed and simulated $\mathrm{N}$ yields resulting from residual $\mathrm{N}$ 
Table 9 Statistical indices for the goodness of fit between observed and simulated $\mathrm{N}$ yields of cut grassland resulting from just the residual $\mathrm{N}$ effects (RES) and from 'first year' and residual $\mathrm{N}$ effects together (TOTAL) of manures (the various types being pooled), as related to the relative decomposition rates (RDR) of organic $\mathrm{N}$ during the year of application $\left(\mathrm{RDR}_{\text {norgl }}\right.$, year $\left.{ }^{-1}\right)$ and during subsequent years $\left(\mathrm{RDR}_{\text {norg2 }}\right.$, year $\left.^{-1}\right)$

\begin{tabular}{|c|c|c|c|c|c|c|c|c|c|}
\hline Manure type & Treatments & Number of observations & $\mathrm{RDR}_{\text {norg1 }}$ & $\mathrm{RDR}_{\text {norg2 }}$ & $M^{\mathrm{a}}$ & $\mathrm{SE}_{M}^{\mathrm{b}}$ & $R^{\mathrm{c}}$ & $\pm 10^{\mathrm{d}}$ & $\pm 20^{\mathrm{d}}$ \\
\hline \multirow[t]{15}{*}{ All } & \multirow[t]{15}{*}{ RES } & \multirow[t]{15}{*}{84} & \multirow[t]{3}{*}{0.00} & 0.10 & 5 & 1.4 & 61 & 44 & 71 \\
\hline & & & & 0.20 & 15 & 2.0 & 61 & 42 & 57 \\
\hline & & & & 0.33 & 22 & 2.8 & 59 & 29 & 43 \\
\hline & & & \multirow[t]{3}{*}{0.10} & 0.10 & 3 & 1.4 & 61 & 56 & 88 \\
\hline & & & & 0.20 & 13 & 1.8 & 61 & 44 & 64 \\
\hline & & & & 0.33 & 19 & 2.5 & 59 & 36 & 51 \\
\hline & & & \multirow[t]{3}{*}{0.20} & 0.10 & 2 & 1.3 & 60 & 57 & 89 \\
\hline & & & & 0.20 & 10 & 1.6 & 61 & 48 & 75 \\
\hline & & & & 0.33 & 16 & 2.2 & 59 & 39 & 58 \\
\hline & & & \multirow[t]{3}{*}{0.33} & 0.10 & 0 & 1.3 & 59 & 61 & 90 \\
\hline & & & & 0.20 & 7 & 1.5 & 60 & 50 & 81 \\
\hline & & & & 0.33 & 12 & 1.9 & 59 & 37 & 68 \\
\hline & & & \multirow[t]{3}{*}{0.50} & 0.10 & -3 & 1.4 & 57 & 55 & 87 \\
\hline & & & & 0.20 & 2 & 1.4 & 59 & 58 & 88 \\
\hline & & & & 0.33 & 6 & 1.6 & 58 & 52 & 82 \\
\hline \multirow[t]{15}{*}{ All } & \multirow[t]{15}{*}{ TOTAL } & \multirow[t]{15}{*}{108} & \multirow[t]{3}{*}{0.00} & 0.10 & -3 & 2.4 & 90 & 45 & 76 \\
\hline & & & & 0.20 & 8 & 2.6 & 89 & 39 & 56 \\
\hline & & & & 0.33 & 18 & 3.0 & 86 & 31 & 51 \\
\hline & & & \multirow[t]{3}{*}{0.10} & 0.10 & -3 & 2.1 & 93 & 51 & 81 \\
\hline & & & & 0.20 & 8 & 2.3 & 91 & 41 & 62 \\
\hline & & & & 0.33 & 16 & 2.7 & 89 & 33 & 52 \\
\hline & & & \multirow[t]{3}{*}{0.20} & 0.10 & -2 & 1.9 & 94 & 53 & 84 \\
\hline & & & & 0.20 & 7 & 2.0 & 93 & 42 & 74 \\
\hline & & & & 0.33 & 15 & 2.4 & 91 & 34 & 56 \\
\hline & & & \multirow[t]{3}{*}{0.33} & 0.10 & -1 & 1.7 & 95 & 55 & 85 \\
\hline & & & & 0.20 & 6 & 1.8 & 95 & 46 & 75 \\
\hline & & & & 0.33 & 13 & 2.2 & 93 & 32 & 62 \\
\hline & & & \multirow[t]{3}{*}{0.50} & 0.10 & 0 & 1.7 & 96 & 51 & 77 \\
\hline & & & & 0.20 & 5 & 1.8 & 95 & 51 & 78 \\
\hline & & & & 0.33 & 10 & 2.1 & 94 & 43 & 72 \\
\hline
\end{tabular}

${ }^{\mathrm{a}}$ Mean difference between observed and simulated values, positive values denoting underestimated yields in simulation ( $\mathrm{kg} \mathrm{N}^{-1}$ )

${ }^{\mathrm{b}}$ Standard error of the mean difference $\left(\mathrm{kg} \mathrm{N} \mathrm{ha}^{-1}\right)$

${ }^{\mathrm{c}}$ Coefficient of correlation (\%)

${ }^{\mathrm{d}}$ Percentage of simulations within \pm 10 or $\pm 20 \mathrm{~kg} \mathrm{~N} \mathrm{ha}^{-1}$ year $^{-1}$ of the corresponding observations

effects only, were below $20 \mathrm{~kg} \mathrm{~N} \mathrm{ha}^{-1}$ year $^{-1}$ in approximately $90 \%$ of the cases when the value of $\mathrm{RDR}_{\text {norg2 }}$ was limited to 0.10 year $^{-1}$ (Table 9).

Our calculations on the implications of annually repeated manure applications indicated that it would take 7 yearly applications to raise the NFRV of undigested slurry from a simulated initial $55-60 \%$ to $75 \%$ in the 'diminishing RDR' scenario, adopting a $\mathrm{RDR}_{\text {norg1 }}$ of 0.33 year $^{-1}$, a RDR $\mathrm{Rorg}_{2}$ of 0.10 year $^{-1}$ during the first four residual years and a $\mathrm{RDR}_{\text {norg2 }}$ gradually dropping to 0.02 year $^{-1}$ in the subsequent
8 years. In the 'constant RDR' scenario, adopting a $\mathrm{RDR}_{\text {norg1 }}=\mathrm{RDR}_{\text {norg2 }}$ of 0.10 year $^{-1}$, such an increase would need 10 yearly applications. It would take around 20 ('constant RDR') to 40 ('diminishing RDR') yearly applications to raise the NFRV of farm yard manure from an simulated initial $20-30 \%$ to a similar value. Note that the NFRV of FYM during the first few years of applications was better simulated with a $\mathrm{RDR}_{\text {norg1 }}$ of 0.33 year $^{-1}$ than with 0.10 year $^{-1}$ (Fig. 6).

Both the observed and the simulated NFRV of anaerobically digested slurry were higher in the 
Fig. 5 Observed $\mathrm{N}$ yields of cut grassland versus simulated $\mathrm{N}$ yields, adopting a relative decomposition rates (RDR, year ${ }^{-1}$ ) of 0.02 for (combined labile and stable) soil organic $\mathrm{N}$ in the upper $30 \mathrm{~cm}$ layer $(\mathrm{LON}+\mathrm{SON})$, 0.33 for the organic $\mathrm{N}$ in manure decomposing during the year of application (Norg1) and 0.10 for the remaining organic $\mathrm{N}$ (Norg2) decomposing during subsequent years ( $a r$ row, indicating fertilized treatments in 2002)

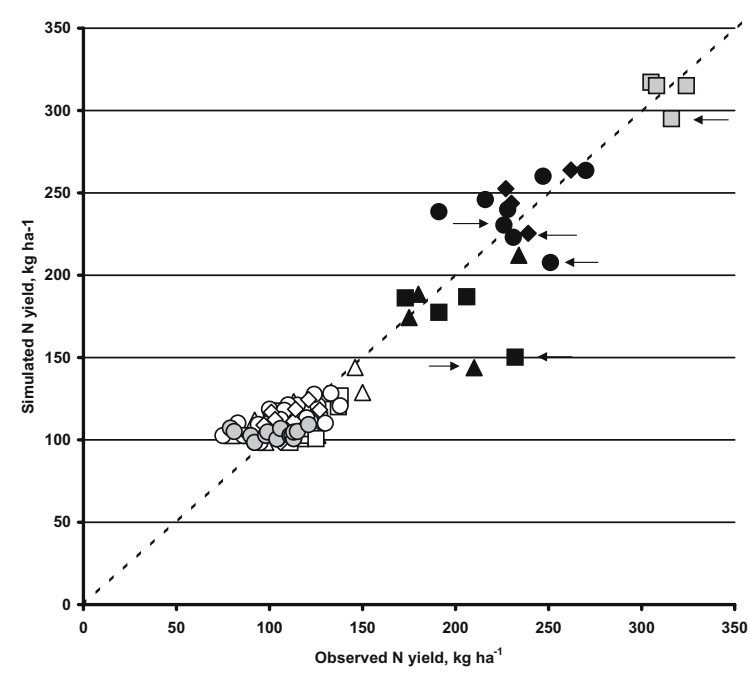

first year of application, as a consequence of the conversion of organic $\mathrm{N}$ into ammonium $\mathrm{N}$ (Table 2). The corresponding lower annual input of organic $\mathrm{N}$ affected the residual $\mathrm{N}$ effect of digested slurry negatively according to our simulations, which was more or less supported by the observations (Table 7). The observed difference in NFRV of digested and undigested slurry hence declined, the larger the number of years taken into account (Fig. 7).

Simulated total $\mathrm{N}$ losses could not be confronted with observations because losses were not measured in the experiment. The simulated change of the soil $\mathrm{N}$ pool $(0-30 \mathrm{~cm})$ amounted to $-48,-11$, and $+63 \mathrm{~kg} \mathrm{~N}$ $\mathrm{ha}^{-1}$ year $^{-1}$ for CONT, CANs and FYMs treatments, respectively (according to 'diminishing RDR' sce- nario with an adopted $\mathrm{RDR}_{\text {norg1 }}, \mathrm{RDR}_{\text {norg2 }}$ and $\mathrm{RDR}_{\text {lon }+ \text { son }}=0.33,0.10$ and 0.02 year $^{-1}$, respectively). These simulated changes did not agree with the observations, as indicated in the previous section, although the observed differences between treatments were reasonably predicted.

Repeated applications of manures impact on the $\mathrm{N}$ supplying power of soils and thus on the $\mathrm{N}$ yield of crops from which $\mathrm{N}$ is withheld. This is shown by the simulated yield depression of unfertilized grassland that has either been manured for 30 years at a rate of $250 \mathrm{~kg}$ undigested slurry-N ha ${ }^{-1}$ year $^{-1}$ complemented with mineral fertilizer $\mathrm{N}$ up to a level to attain a harvestable yield of $300 \mathrm{~kg} \mathrm{~N}^{-1}$ year $^{-1}$, or has been fertilized up to this yield level with mineral fertilizer $\mathrm{N}$ only (Fig. 8).
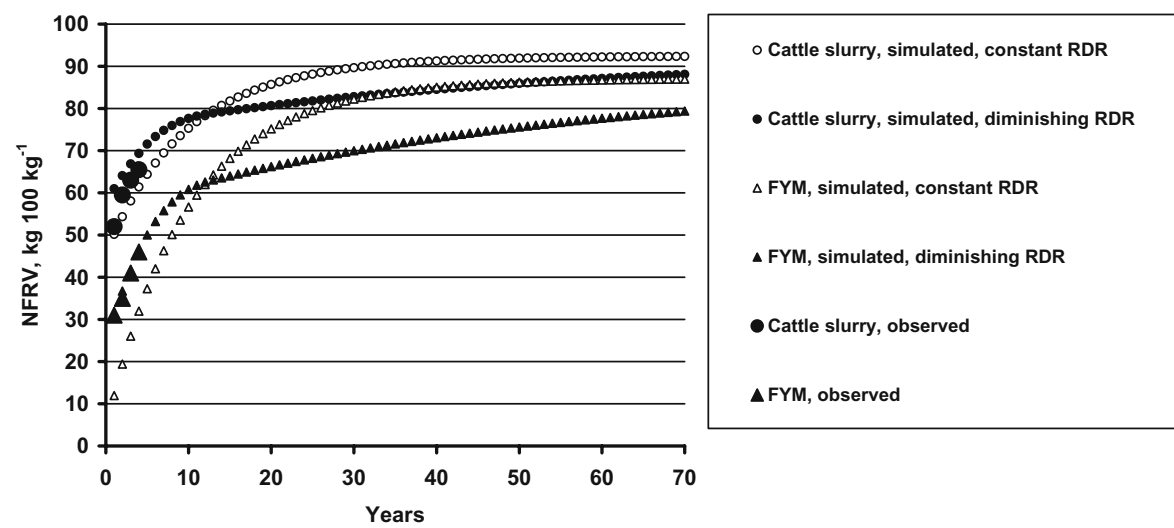

Fig. 6 Observed and simulated $\mathrm{N}$ fertilizer replacement value $\left(\mathrm{kg} \mathrm{N} 100 \mathrm{~kg} \mathrm{~N}^{-1}\right.$ ) of injected cattle slurry (mean composition of S1UN and S2UN) and surface applied farm yard manure (FYM), simulations following a constant decomposition rate of organic

manure-N ( 0.10 year $\left.^{-1}\right)$ or a diminishing decomposition rate

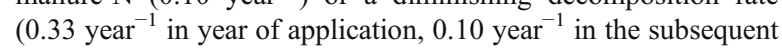
4 years, decreasing by 0.01 per year to a final value of 0.02 year $^{-1}$ afterwards) 
Fig. 7 Observed and simulated $\mathrm{N}$ fertilizer replacement value $(\mathrm{kg} \mathrm{N} 100 \mathrm{~kg}$ $\mathrm{N}^{-1}$ ) of injected untreated cattle slurry (S1UNi) and injected anaerobically digested cattle slurry (S1ADi), simulations following a constant decomposition rate of organic manure-N $\left(0.10\right.$ year $\left.^{-1}\right)$

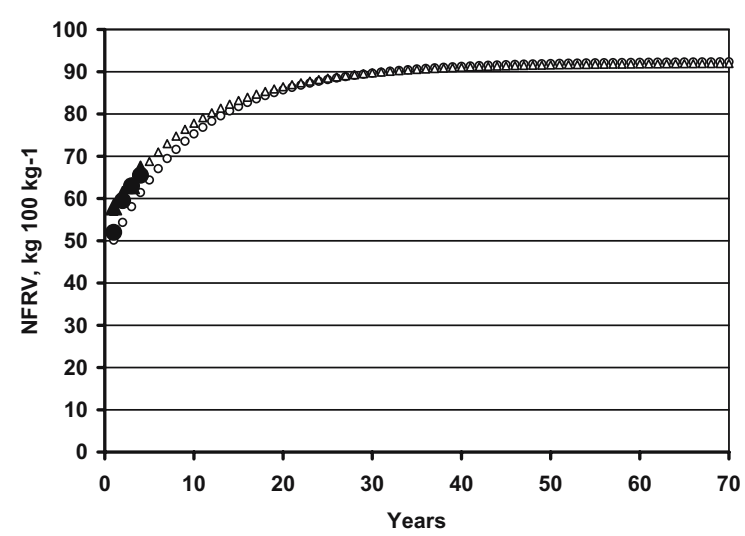

\section{Discussion}

Nitrogen pollution per unit farm produce is determined my many interacting factors, among which the utilization of applied manure $\mathrm{N}$ is one (Schröder et al. 2005b). Incorrect estimates of the short-term and residual $\mathrm{N}$ effects of manure could thus have a negative effect on resource utilization. Residual $\mathrm{N}$ effects of applied manure do not become fully expressed in experiments lasting just 1 year, either because manured treatments initially lack the $\mathrm{N}$ contributions from residual $\mathrm{N}$ of prior applications when the site has not been manured at equally high rates, or because control treatments benefit as much as manured treatments from residual $\mathrm{N}$ originating from the period before the experiment started. The ob- served NFRV's of undigested cattle slurries in the year of application, were in good agreement with short term experiments elsewhere (Schils and Kok 2003; Reijs et al. 2007). The observed NFRV of surface applied slurry was lower than that of injected slurry, indicating that a negative effect of the probable $\mathrm{NH}_{3}$ loss on $\mathrm{N}$ yields was apparently not compensated by a positive effect of the avoided mechanical damage resulting from the injection tines. This observation is in agreement with the findings of Schils and Kok (2003).

The establishment of 'manuring histories' in our experiment also clearly demonstrated residual $\mathrm{N}$ effects of manure. However, due to the limited duration of the experiment we were not able to fully appreciate the long-term consequences. We have tried to circumvent this shortcoming by combining the

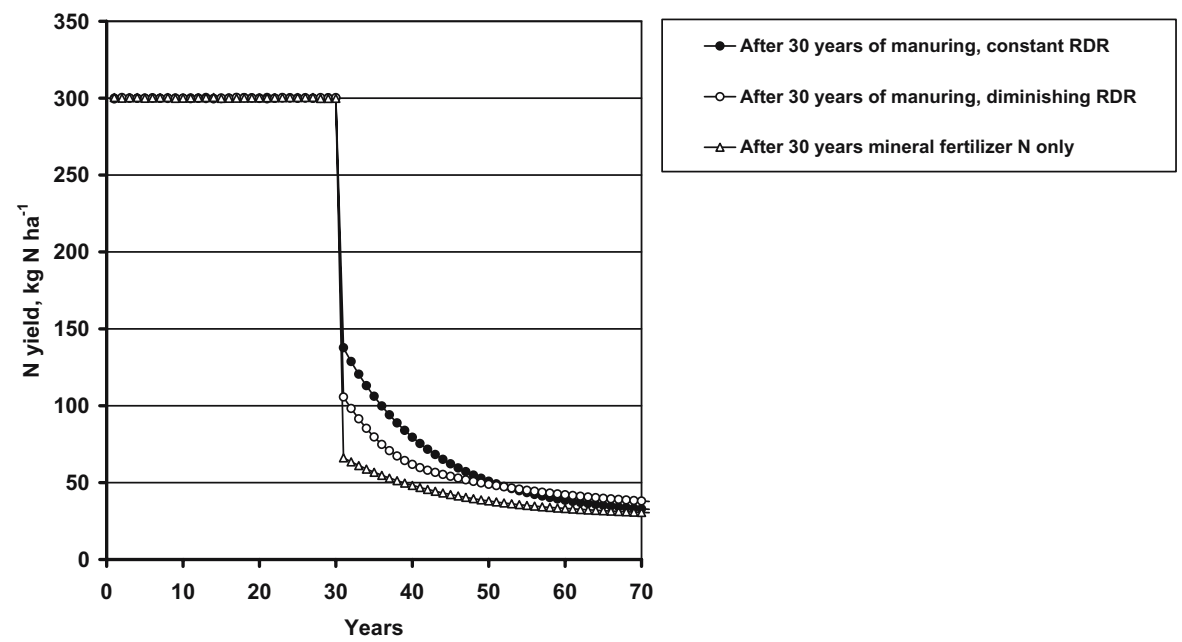

Fig. 8 Simulated $\mathrm{N}$ yield reduction of unfertilized grasslands that have either been manured for 30 years at a rate of $250 \mathrm{~kg}$ undigested slurry- $\mathrm{N} \mathrm{ha}{ }^{-1}$ complemented with mineral fertilizer $\mathrm{N}$ up to a level to attain a harvestable yield of $300 \mathrm{~kg} \mathrm{~N} \mathrm{ha}^{-1}$ year $^{-1}$, or have been fertilized up to this yield level with mineral fertilizer $\mathrm{N}$ only, simulations following a constant decomposition rate of organic manure-N $\left(0.10\right.$ year $\left.^{-1}\right)$ or a diminishing decomposition rate $\left(0.33\right.$ year $^{-1}$ in year of application, 0.10 year $^{-1}$ in the subsequent 4 years, decreasing by 0.01 per year to a final value of 0.02 year $^{-1}$ afterwards) 
results with a simple model. This model assumes a first order decay of organic manure and allows for different RDR's in the year of application and in the following years.

The model did not succeed in predicting the observed dynamics of the soil N pool. Probably, this was due to the impossibility of accurately assessing small changes of the soil $\mathrm{N}$ pool against a large background value, as earlier encountered by Schröder et al. (2005a).

The yield response of cut grassland to fertilizer $\mathrm{N}$ and manures, however, was reasonably well simulated, bearing in mind that weather effects were not incorporated into the model. Our analysis indicated that the decomposition rate of manures may be larger in the year of application than in subsequent years. Our results suggest that the RDR of organic manure N in the year of application $\left(\mathrm{RDR}_{\text {norg1 } 1}\right)$ is closer to values around 0.20 than 0.50 year $^{-1}$. The latter value is as yet the assumption of extension services in The Netherlands, based on the results of hydrolysis of Norg in sulphuric acid (Sluijsmans and Kolenbrander 1976). The residual $\mathrm{N}$ effect of manures was better predicted by adopting a RDR in later years $\left(R R_{n o r g}\right)$ of 0.10 than of 0.20 year $^{-1}$ or more. These RDR values are lower than the $0.25-0.33$ year $^{-1}$ derived from two recent experiments in arable crops on similar soil types (Schröder et al. 2006). Although it must be noted that the present model description differed slightly from that of Schröder et al. (2006), this could imply that the absence of tillage reduces decomposition rates. An analysis of the existing literature on manure decomposition, as presented in Schröder et al. (2005a), indicates that the observed RDR's of manure range from as little as 0.10 to as much as 0.50 year $^{-1}$. This broad range does not question the difference in principle between short term and long term NFRV's of manures; the value of the RDR does, however, affect the number of years needed to attain equilibrium between annual inputs of organic $\mathrm{N}$ and the annual decomposition of this material. Differences in RDR are probably attributable to differences in climate and soil type (Hassink 1994; Sörensen and Amato 2002) and the composition of manures as a result of the use of bedding material and diet composition (Chadwick et al. 2000; Kebreab et al. 2001; Reijs et al. 2007).

Sörensen and Amato (2002) presented data from which residual $\mathrm{N}$ effects of pig slurry of 5 and $2 \%$ of the total $\mathrm{N}$ input could be calculated for the first and second year after the year of application, respectively, according to the difference method as used in the present paper. An isotope substitution study of Sörensen and Thomsen (2005) pointed at a residual $\mathrm{N}$ effect of pig slurry of $3 \%$ of the total $\mathrm{N}$ input in the first year following the year of application. Sörensen (2004) reported residual effects of cattle slurry on the $\mathrm{N}$ uptake of barley followed by a cover crop. The residual effect on $\mathrm{N}$ yields amounted to $5-7 \%$ and $5 \%$ of the total $\mathrm{N}$ input in the first and second year, respectively, when effects on barley and a following cover crop were pooled to approximate the length of our grassland growing season. These estimates may be conservative as their test crops received the recommended mineral $\mathrm{N}$ rate, making them less responsive to residual $\mathrm{N}$. The previous values from the literature are in good agreement with our residual effects of undigested cattle slurries of $1-10 \%$ (first residual year), 2-5\% (second residual year), and $1-4 \%$ (third residual year) of the total $\mathrm{N}$ input (Table 7), although our slurries contained more Norg per $\mathrm{kg}$ total $\mathrm{N}$. When related to the input of organic N, the values observed by Sörensen (2004) corresponded with an apparent decay of $0.11-0.16$ year $^{-1}$ of the applied amount of organic $\mathrm{N}$ in the slurry. Again, this is in reasonable agreement with our 0.10 year $^{-1}$.

Our experiments and the subsequent modelling both indicated that manures with a relatively large first year NFRV (e.g. anaerobically digested slurry) exhibited a relatively small residual $\mathrm{N}$ effect, compared to the untreated injected slurries and, to a lesser extent, farm yard manure. This trend is in agreement with simulations of Berntsen et al. (2007), although their absolute values of residual $\mathrm{N}$ effects (expressed as the NFRV of manures applied to barley after 30 annual applications) were smaller than ours.

Whatever the exact number of years needed to attain equilibrium between annual organic $\mathrm{N}$ inputs and their full apparent decay, the implication of this is that the initially perceived differences in NFRV between anaerobically digested slurry, untreated slurry and farm yard manure, will largely disappear with time. It is hence questionable to base preferences for certain manure types on just their short-term NFRV which is, self-evidently, closely linked to the ammonium content and the $\mathrm{C}$ to total $\mathrm{N}$ ratio (Reijs et al. 2007), provided that $\mathrm{NH}_{3}$ loss is avoided. If residual $\mathrm{N}$ effects are ignored, the long-term environmental 
impact may be underestimated too. Consequently, it seems short-sighted to call seemingly inert vegetable and garden waste composts 'environmentally benign', just because their initial NFRV is low (Nevens and Reheul 2003). Any manure with a narrow mineral N to total $\mathrm{N}$ ratio can in the long run be associated with an untimely release of $\mathrm{N}$ and this could increase leaching losses. This may in particular apply to arable rotations with long fallow periods (Sörensen 2004).

The present plea to take better account of the long term NFRV when deciding on application rates, has yet another implication. When $\mathrm{N}$ recommendations for a crop are partly based on trials that were carried out on sites to which manures have been amply applied before the experiments started, the true $\mathrm{N}$ requirements of that crop will be underestimated. One may reason that these combined biases of underestimated NFRV's and N requirements, will compensate each other in our advices to farmers. However, site-specific $\mathrm{N}$ management requires a better disentanglement of both shortcomings. If not, the long term consequences of reduced $\mathrm{N}$ rates for yields will not be fully acknowledged (Motavalli et al. 1992). These consequences of residual $\mathrm{N}$ effects deserve attention too, in addition to a correct estimate of the long term NFRV of manure. Farming systems are by nature dynamic due to changing economic and environmental drivers. Crop yields and environmental quality do not respond instantaneously to changed practices, however. As such farming systems are always underway to new equilibria without ever reaching them really. This contributes to uncertainties. The present model may help to improve our quantitative understanding of the impact of former and future nutrient management strategies, thus reducing these uncertainties.

Acknowledgments Funding for this work from the Dutch Ministry of Agriculture, Nature and Food quality (LNV-DWK programs 398 and BO5) is gratefully acknowledged. We would also like to thank the anonymous reviewers for their constructive comments on an earlier version of this paper.

\section{References}

Addiscott TM (2005) Nitrate, agriculture and the environment. CABI, Wallingford, UK, 1-279

Addiscott TM, Whitmore AP (1987) Computer simulation of changes in soil mineral nitrogen and crop nitrogen during autumn, winter and spring. J Agr Sci 109:141-157
Berntsen J, Petersen BM, Sörensen P, Olesen JE (2007) Simulating residual effects of animal manures using $15 \mathrm{~N}$ isotopes. Plant Soil 290:173-187

Beijer L, Westhoek H (1996) Fertilisers for cattle farming (In Dutch). Publicatie 17, Informatie - en Kennis Centrum Landbouw Ede, The Netherlands, 1-109

Chadwick DR, John F, Pain BF, Chambers BJ, William J (2000) Plant uptake of nitrogen from the organic nitrogen fraction of animal manures: a laboratory experiment. J Agr Sci 134:159-168

Chae YM, Tabatabai MA (1986) Mineralization of nitrogen in soils amended with organic wastes. J Env Qual 15(2): 193-198

Coleman K, Jenkinson DS (1996) RothC-26.3: a model for the turnover of carbon in soil. In: DS Powlson, P Smith P, JU Smith (eds) Evaluation of soil organic matter models. Harpenden, UK, pp 237-246 (Series I Vol 38)

Curtin D, McCallum FM (2004) Biological and chemical assays to estimate nitrogen supplying power of soils with contrasting management histories. Austr J Soil Res 42:737-746

Daudén A, Quilez D, Martinez C (2005) Residual effects of pig slurry applied to a Mediterranean soil on yield and $\mathrm{N}$ uptake of a subsequent wheat crop. Soil Use Manage 20:156-162

Gutser R, Ebertseder Th, Weber A, Schram M, Schmidhalter U (2005) Short-term and residual availability of nitrogen after long-term application of organic fertilizers on arable land. J Plant Nutr Soil Sci 168:439-446

Hart, PBS, Powlson D, Poulton PR, Johnston AE, Jenkinson DS (1993) The availability of the nitrogen in the crop residues of winter wheat to subsequent crops. J Agric Sci Camb 121:355-362

Hassink J (1994) Effects of soil texture and grassland management on soil organic $\mathrm{C}$ and $\mathrm{N}$ and rates of $\mathrm{C}$ and $\mathrm{N}$ mineralization. Soil Biol Biochem 26:1221-1231

Huijsmans JFM (1999) Manure application. In: JHAM Steenvoorden, WJ Bruins, MM Van Eerdt, MW Hoogeveen, N Hoogervorst, JFM Huijsmans, H Leneman, HG Van der Meer, GJ Monteny, FJ De Ruijter (eds) Monitoring of national ammonia emissions from agriculture (In Dutch), Reeks Milieuplanbureau 6. Alterra, Wageningen, The Netherlands, pp 65-75

Kebreab E, France J, Beever DE, Castillo AR (2001) Nitrogen pollution by dairy cows and its mitigation by dietary manipulation. Nutr Cycl Agroecosys 60:275-285

Lagreid M, Böckman OC, Kaarstad O (1999) Agriculture, fertilizers and the environment. CABI, Wallingford, UK, pp 1-294

Motavalli PP, Bundy LG, Andraski TW, Peterson AE (1992) Residual effects of long-term fertilization on nitrogen availability to corn. J Prod Agric 5:363-368

Nevens F, Reheul D (2003) The application of vegetable, fruit and garden waste in addition to cattle slurry in a silage maize monoculture: nitrogen availability and use. Eur J Agron 22:189-203

Osmond DL, Lathwell DJ, Riha SJ (1992) Prediction of longterm fertilizer nitrogen requirements of maize in the tropics using a nitrogen balance model. Plant Soil 143:61-70 
Powlson, DS (1997) Integrating agricultural nutrient management with environmental objectives - current state and future prospects. In: Proceedings no 402, International Fertiliser Society, York, UK, pp 1-42

Reijs, JW, Sonneveld MPW, Sörensen P, Schils RLM, Groot JCJ, Lantinga EA (2007) Effects of different diets on utilization of nitrogen from cattle slurry applied to grassland on sandy soil in The Netherlands. Agri Ecos Env 118:65-79

Schils RLM, Kok I (2003) Effects of cattle slurry manure management on grass yield. Neth J Agric Sci 51(1-2):41-65

Schröder JJ (2005) Manure as a suitable component of precise nitrogen nutrition. In: Proceedings no. 574, International Fertiliser Society, York, UK, pp 1-32

Schröder JJ, Van Keulen H (1997) Modelling the residual N effect of large slurry applications on maize land in The Netherlands. Neth J Agric Sci 45:477-494

Schröder JJ, Stevens RJ (2004) Optimising N additions: can we integrate fertiliser and manure use? In: DJ Hatch, DR Chadwick, SC Jarvis, JA Roker (eds) Controlling nitrogen flows and losses. Wageningen Academic, Wageningen, The Netherlands, pp 586-593

Schröder JJ, Jansen AG, Hilhorst GJ (2005a) Long-term nitrogen supply from cattle slurry. Soil Use Manage 21:196-204

Schröder JJ, Bannink A, Kohn R (2005b) Improving the efficiency of nutrient use in cattle operations. In: E Pfeffer, AN Hristov (eds) Nitrogen and phosphorus nutrition of cattle. CABI, Wallingford, UK, pp 255-279

Schröder JJ, Van Dijk W., Hilhorst GJ, Van Schooten H, Bruinenberg M (2006) Long term N fertilizer value of cattle slurry applied to maize. In: JJ Schröder, JJ Neeteson (eds) $\mathrm{N}$ management in agrosystems in relation to the Water Framework Directive. Proceedings of the 14th N Workshop, Plant Research International, Wageningen, The Netherlands, pp 170-172 (Report 116)

Schröder JJ, Aarts HFM, Van Middelkoop JC, Schils RLM, Velthof GL, Fraters B, Willems WJ (2007) Permissible manure and fertilizer use in dairy farming systems on sandy soils in The Netherlands to comply with the Nitrates Directive target. Eur J Agron 27:102-114

Silgram M, Shepherd M (1997) The effect of cultivation on soil nitrogen mineralisation: a review. Report to MAFF, Roame NT 1318, ADAS, Boxword Cambridge, pp 1-40

Sissingh HA (1971) Analytical technique of the Pw method used for the assessment of the phosphate status of arable soils in The Netherlands. Plant Soil 34:483-486

Sluijsmans CMJ, Kolenbrander GJ (1976) The nitrogen efficiency of farm yard manure in the short and long run (In Dutch). Stikstof 7(83/84):349-354

Sonneveld MPW, Monteny GJ, De Vos JA, Schröder JJ, Lantinga E, Verhoeven F, Bouma J (2007) A whole-farm strategy to reduce environmental impacts of nitrogen. J Env Qual (in press)

Sörensen P (2004) Immobilisation, remineralisation and residual effects in subsequent crops of dairy cattle slurry nitrogen compared to mineral fertilizer nitrogen. Plant Soil 267:285-296

Sörensen P, Amato M (2002) Remineralisation and residual effects of $\mathrm{N}$ after application of pig slurry to soil. Eur $\mathrm{J}$ Agron 16:81-95

Sörensen P, Thomsen IK (2005) Separation of pig slurry and plant utilization and loss of nitrogen-15 labeled slurry nitrogen. Soil Sci Soc Am J 69:1644-1651

Whitmore AP, Schröder JJ (1996) Modelling the change in soil organic $\mathrm{C}$ and $\mathrm{N}$ in response to applications of slurry manure. Plant Soil 184:185-194

Whitmore AP, Bradburry NJ, Johnson PA (1992) The potential contribution of ploughed grassland to nitrate leaching. Agric Ecosys Env 39:221-233

Wolf J, Van Keulen H (1989) Modelling long-term crop response to fertilizer and soil nitrogen. II. Comparison with field results. Plant Soil 120:23-38

Wolf J, De Wit CT, Van Keulen H (1989) Modeling long-term crop response to fertilizer and soil nitrogen. I. The model. Plant Soil 120:11-22 